halogen content from the Gulf of Oman, that has gradually sunk downwards off the west coast of India and the western slopes of the Laccadive and Maldive Archipelagoes.

The results obtained by repeating our observations in the Socotra current across the entrance to the Gulf of Aden show a considerable degree of similarity with those obtained during our earlier work in September (cf. Nature, 133, 67, Fig. 3 and 87, Fig. 2). In the Straits of Bab el Mandeb, however, conditions were very different and now (April-May) agree closely with the results previously obtained by the Magnaghi and Ormonde at this time of the year.

\section{Biological Results}

- During our cruise through the Maldive Archipelago a number of observations were made, both

\begin{tabular}{|c|c|c|c|c|}
\hline $\begin{array}{l}\text { Sta- } \\
\text { tion } \\
\text { No. }\end{array}$ & Locality & $\begin{array}{c}\text { Depth } \\
\text { (metres) }\end{array}$ & $\begin{array}{l}\text { Nature of } \\
\text { bottom }\end{array}$ & $\begin{array}{c}\text { Amt. of } \mathrm{H}_{2} \mathrm{~S} \\
\text { (mgm. per litre) }\end{array}$ \\
\hline 137 & $\begin{array}{l}\text { Addu atoll, } \\
\text { N.E. corner }\end{array}$ & 46 & $\begin{array}{l}\text { White, chalky } \\
\text { mud }\end{array}$ & $4 \cdot 90$ \\
\hline 139 & $\begin{array}{l}\text { Kolumadulu } \\
\text { atoll, E. side }\end{array}$ & 57 & Coral sand & nil. \\
\hline 141 & $\begin{array}{l}\text { Mulaku } \\
\text { atoll, W. side }\end{array}$ & 44 & $\begin{array}{l}\text { Coarse sand, } \\
\text { shells, coral } \\
\text { and conglom- } \\
\text { erate rock }\end{array}$ & nil. \\
\hline $\begin{array}{l}142 \\
(a)\end{array}$ & $\begin{array}{l}\text { Fadiffolu atoll, } \\
\text { F. side }\end{array}$ & 31 & $\begin{array}{l}\text { Sand and white } \\
\text { mud }\end{array}$ & $3 \cdot 29$ \\
\hline $\begin{array}{l}142 \\
(b)\end{array}$ & ditto. & 37 & $\begin{array}{l}\text { Cream-coloured } \\
\text { mud }\end{array}$ & $2 \cdot 26$ \\
\hline 144 & $\begin{array}{l}\text { Fadiffolu atoll, } \\
\text { W. side }\end{array}$ & 31 & $\begin{array}{l}\text { Coarse coral and } \\
\text { shell sand }\end{array}$ & nil. \\
\hline 147 & $\begin{array}{l}\text { Horsburgh } \\
\text { atoll, N. side }\end{array}$ & 27 & $\begin{array}{l}\text { Soft cream- } \\
\text { coloured mud }\end{array}$ & nil. \\
\hline 160 & $\begin{array}{l}\text { Horsburgh } \\
\text { atoll, N. side }\end{array}$ & 37 & $\begin{array}{l}\text { Cream-coloured } \\
\text { mud }\end{array}$ & $7 \cdot 73$ \\
\hline 161 & $\begin{array}{l}\text { S. Malos- } \\
\text { side }\end{array}$ & 46 & Coarse sand & nil. \\
\hline
\end{tabular}

in the shallow water of the lagoons and in the deeper waters of Kardiva Channel and the western slopes.
One interesting and important discovery that we made was the presence of sulphuretted hydrogen gas in the bottom-deposit of several of the lagoons. The details are given in the accom panying Table.

It will be noted that in every case the presence of the sulphuretted hydrogen is associated with a fine white or cream-coloured mud, and in most cases where the gas was found there were thickly wooded and fertile islands in the near vicinity, so that it seems probable that this gas is caused by the decomposition in the mud of organic material derived from the vegetation of the islands. To what extent the presence of this gas, in such quantities as are indicated above, may influence the fauna or inhibit the growth of coral is a problem that requires investigation.

A slight trace of sulphuretted hydrogen was also detected in a bottom deposit of green mud, obtained at a depth of 95 metres, on the Arabian coast in lat. $13^{\circ} 51^{\prime} 30^{\prime \prime} \mathrm{N}$., long. $47^{\circ} 49^{\prime} 12^{\prime \prime} \mathrm{E}$. (Station 189) in the Gulf of Aden, and this possibly represents a western extension of the conditions found to be present farther to the east off Cape Ras-al-Hadd.

The fauna of Kardiva Channel and the flat level of King Fuad Bank proved to be a rich one, but on the western slopes the catches were disappointing. This may be due partly to the difficulty of trawling successfully on a steep slope, but it would also appear probable that on this western side of the Maldive ridge the fauna is impoverished, and in the depth of the north-eastern basin of the Arabian Sea a trawl of two hours' duration on the Red Clay at a depth of 4,718-4,793 metres yielded no living organisms at all.

\title{
The Green Plant and its Messages to Mankind*
}

IN this elanging world of constant change, one thing stands fast: the green plant, the greatest wonder of the world, the engineer of life. Some of its messages it sends direct to us by its own special messengers, for example, the vitamins ; others it leaves scientific interpreters to convey. The green plant is the source of the paper upon which the latter messages are written, and when the paper perishes, the plant gathers up the fragments and welds them again into leaf and flower and fibre. It is also the source of coal, of wood, of dyes, spices, fabrics and wine.

The life of the simplest of green plants, Chlamydomonas, tells us of feats of structural engineering beyond human power, and suggests hydraulic systems so perfect that, in spite of its

* Summary of the Thomas Hawksley lecture, "The Green Plant as Agricultural Engineer", given by Sir Frederick Keeble before the Institution of Mechanical Engineers on October 26, 1934. fragility, the green plant can sustain pressures comparable with those of the steam-engine, and that too without shriek or moan. The individual Chlamydomonas is invisible to the naked eye, yet so numerous that at certain times they form a green scum on the edge of the sea and on inland waters. Chlamydomonas is a plant-animal. In its green youth it is active and self-contained; the only materials for its sustenance are solutions of carbon dioxide, simple nitrogen compounds and mineral salts. From these it builds up sugar and starch by photosynthesis, and amino-compounds and proteins with the help of oxygen derived from nitrates in the sea-water. A powerful swimmer for its size, it propels itself by means of long, slender protoplasmic threads towards the light. But these 'salad' days come to an end. The solitary swimmers unite by fusion, protoplasm with 
protoplasm, nucleus with nucleus, and the spherical product settles down on some debris in shallow water. The chlorophyll steals away, and what was before a plant is now an animal, depending, like all animals, on external supplies of food. Its body grows, subdivides, and the parts subdivide again, flagella appear, and the plant-form of Chlamydomonas is born anew. The message to mankind is patent to all : "The green plant makes the best of both worlds ; go thou and do likewise!"

Whatever man may have done with his own world, he certainly has not made the best of the other world-the world of the green plant; if he had, his own would be far brighter and happier. What has he done for the green plants' world ? By incessant labour he has made little plots of earth more fruitful; but invading armies and marauding bands have laid waste great tracts of fertile land. He has changed weeds into bountiful cereal crops, has ravished virgin soils, only to move on and let the weeds come back again. $\mathrm{He}$ has felled forests and burned them down, until the earth which the forest used to shelter is driven by storms of rain to seek refuge in the sea. Man by his intelligence and industry has done much for the green plant, but by his ignorance and improvidence he has done far more for its undoing.

The green plant makes a brave show, clothing the earth with verdure and adorning it with garlands of flowers; but in the main it leads a life of poverty. The sun gives it abundant energy ; earth and atmosphere are, however, more niggardly. In spite of the ample amount of carbon dioxide in the air, its conoentration is too low to allow the green leaves to keep up their full synthetic powers. Wheat is pre-eminent as a thrifty plant, and will stand a fair amount of neglect. That is why it is grown so universally, and why, grown even as it is, the crop feeds some 300 million people. The kinds mostly grown can withstand rough weather and get along with scanty supplies of food. Inured to hardship like the farmer himself, they respond but grudgingly to more generous treatment; but some kinds respond to nitrogen more readily than others. The wheatlands of the world could feed thrice 300 million people if they were relieved of chronic hunger for nitrogen and phosphates. The grasslands of the world are even more hungry, and the landscape often reveals their poverty. Grass makes a brave showing, which adversity cannot mar; but the brave show is brief. The short life of the grass growing on the thin soils of the Cotswold hills was observed by Shakespeare, as we observe it to-day, and he must have had this fact in mind when he wrote: "Everything that grows holds in perfection but a little moment."

The green plant, schooled by age-long privation, has grown adept in the arts of economy. It builds up nitrogen into organic form, breaks it down again, and sends it off to other tissues that need it. These tissues build it up again into protein, only to unbuild it and pass it on once more, like some old garment that is renovated and handed on in thrifty families from the eldest to the youngest child. In spring the grass has but little nitrogen left to pass on ; so the roots get to work early to obtain fresh supplies from the soil; but nitrogen is not readily forthcoming from the soil ; warmth alone can release it. In time, a belated flush of grass appears, but the nitrogen stored by the root is soon used up, and the grass dies down; another wait. The roots accumulate more nitrogen, and late in summer a second flush appears; but it soon dies away. Like Charles Lamb, the grass makes up for coming late by going early. On these half-starved pastures the grazing season is short and intermittent. Is it not likely that the privations endured by the flocks and herds feeding on such pastures have their effect upon mankind?

The poverty of the earth starves mind as well as body; it infects philosophy with pessimism, and burdens the songs of poets with sadness. An earth bountifully supplied with healthy vigorous life would sing the happy songs that Blake wanted men to sing, and hope would again arise in a world desperately in need of it.

Newton found out that apples fall by gravity: it has only recently been learned that it is nitrogenhunger that gives gravity its chance. Apple-trees will bear a good erop annually if they are adequately manured. Sometimes apple-trees planted in a light soil remain unfruitful in spite of adequate dressings of nitrogen ; they are starved of potash, and annual or half-yearly doses will restore them in a year or two. Mineral deficiencies appear to play an equally important, and often decisive, part in inducing disease in both plants and animals. All plants need iron : beans and their like will not grow without boron; tea in Nyasaland has suffered from lack of sulphur; tomatoes in the Philippines have to be given homœopathic doses of copper; some plants cannot thrive without zinc; buckwheat cuts off the heads of its flowers if there is no chlorine in the soil. Potash serves the green plant as a partial substitute for sunshine ; magnesium is essential for the formation of chlorophyll ; and manganese acts as a stimulant to some plants. Among animals, calcium, iodine, fluorine, iron, and almost certainly manganese, copper and silicon, and possibly magnesium, are needed either for building purposes, or for promoting healthy growth and helping the body to resist disease.

The scarcity of essential plant-foods is all but 
universal, and those who are obsessed with the idea of over-production may rejoice in this fact. But the abundance is largely one of half-starved plants and of periodically ill-nourished animals. If food is lacking in quality, its consumer will remain ill-nourished however much he eats. In the days when men lived by calories alone, or thought they did, energy-intake alone mattered; if a man got ill, the cause was ascribed to bad heredity or maleficent microbes. Now we know that starch, sugar, fats and proteins alone will not make us grow or thrive. How this comes about is well shown by the oat shoot. When the extreme tip-not more than $1 \mathrm{~mm}$.-is cut off from the young green shoot, it ceases to grow. If the tip is replaced, the shoot grows again, and the same happens if, instead of the tip being replaced, a cube of agar or gelatin on which the tip has been kept takes its place. The explanation lies in the activity of a chemical messenger (growth-substance) present in the tip of the shoot. Such messengers control the growth of the green plant, and also that of animals. In the human body there are the special chemical messengers known as vitamins, which encourage growth, charm away disease and promote fertility. The green plant is the metropolis from which many of these vitamins set out on their journey to our world, and they reach us either directly in fruit or other fresh green foods, or indirectly in dairy produce and in meat.

To make the best of the world of the green plant, we must utilise to the full our knowledge of the vitamins and their mineral allies on one hand, and of the fertilising power of nitrogen on the other. In carotene, the precursor of vitamin $A$, summer grass is rich, and winter grass is poor. Summer grass, grown with nitrogen, dried quickly and kept out of contact with air, forms an ideal food, rich in carotene, for cows in winter, and the milk and butter they yield is a perfect food for children. Other and possibly greater benefits will follow from the use, as winter fodder, of lucerne, clover and other crops with all their summer vigour in them.

Through vast periods of time, a long winter of scarcity has alternated with a brief summer of abundance; hence primitive man made the waxing and waning of the sun, and of the earth's fertility, the basis of his mythology ; even to-day we celebrate the awakening of life in spring with the Maypole dance.

The nitrogen and mineral scarcities of the earth have directed the evolution of the green plant; may they not also have helped to direct the evolution of mankind? Must not the recurrent malnutrition from which man perforce suffers leave scars upon his body and his mind?

Heredity teaches that our bodily and mental characters are determined irrevocably at birth; the masters of our fate are the genes that reside in the chromosomes of the cell-nucleus. Is it not possible that malnutrition may have undermined the resistance of the chromosomes themselves and weakened the power of the genes? In a world of nitrogen-plenty, the chromosomes might be well nourished, and infertile genes might get the tonic they need to make them fruitful. If that is so, the determinacy in our present view of heredity will disappear, and the age of the creative evolution of mankind will be at hand.

\section{Obituary}

Prof. Georges DreYer, c.B.e., F.R.s.

G EORGES DREYER was born on July 4, 1873, at Shanghai, where his father, Capt. G. H. N. Dreyer of the Danish Royal Navy, was stationed at the time. He was educated in Copenhagen, where he qualified in medicine in 1898 after a very brilliant career as a student. While serving as a medical officer in the Navy, he found time to do some work with Salomonsen in the Pathological Department of the University, and continued this later when he was house physician at the fover hospital. For a time he was responsible for the production of diphtheria antitoxin at the newly established Serum Institute, and he received his M.D. degree in 1900 for a thesis on diphtheria toxin and antitoxin. Dreyer became a Privatdocent in the University of Copenhagen, and carried on an astounding amount of research on a wide variety of subjects-typhoid agglutination, the effect of light on bacteria and protozoa, the action of enzymes, and other subjects. An interest in mathematics had been early stimulated by his father, and in all his varied research he attempted to obtain accurate quantitative results. He found existing methods unsatisfactory for exact quantitative work, and developed new technique in many branches of biological research. He travelled extensively in Scandinavia, Germany, France and England, and came into contact with the leading workers in many fields. An excellent linguist, he spoke Danish, French, German and English fluently.

In 1907, at the early age of thirty-four years, Dreyer was appointed to the professorship of pathology at Oxford. He was the first holder of the chair, although pathology had been taught at Oxford for some years and a new laboratory had been recently built. From 1907 until 1914 he organised and built up the department, and together with his colleagues carried out a considerable amount of research, particularly on the blood volume of mammals-probably one of his most important contributions to science. In 1914 he volunteered for service, and spent much time in France. His great experience of the 